\title{
AN INNOVATION OF ISLAMIC RELIGIOUS EDUCATION IN THE ERA OF THE INDUSTRIAL REVOLUTION 4.0 IN ELEMENTARY SCHOOL
}

\author{
Haidir $^{1}$, Muhammad Arizki ${ }^{2}$ Miftah Fariz ${ }^{3}$ \\ Fakultas Tarbiyah dan Ilmu Keguruan Universitas Islam Negeri Sumatera Utara, Indonesia \\ Hdr.inno74@gmail.com, mhdarizky13@gmail.com, miftahfariz1984@gmail.com
}

\author{
Received: 08-07-2021 Revised: 20-09-2021 Accepted: 30-10-2021
}

\begin{abstract}
Learning Islamic religious education should not turn a blind eye to technological developments that are realized or not have a very large impact on life. Al-Ulum Private Elementary School Medan implements Islamic Religious Education learning innovations using and utilizing technological developments. For example, Teleconference, Google Classroom, Zoom Meeting by utilizing facilities such as e-mail (electronic mail), mobile phones, MP3 players, websites, blogging, search engines, and others. Learning models develop in the form of electronic learning (e-learning), electronic books (e-books), online classes, online discussions, computer-based learning. The use of whiteboards and markers, replaced with the use of Notebook media, LCD Projectors, and so on. Printed sourcebook materials, modules, and student worksheets are replaced with e-books, digital libraries, YouTube, and internet pages. This research is focused on qualitative research using descriptive method. This research intends to examine the natural role of Islamic Religious Education Learning Innovation in the Industrial Revolution Era 4.0 Studies at Al-Ulum Private Elementary School Medan. This research is suitable to use a qualitative research approach with a descriptive method, in revealing the facts as empirical truth in this research..
\end{abstract}

Keywords: Learning innovation, Islamic Religious Education, Industrial Revolution 4.0, Elementary School

\begin{abstract}
Abstrak
Pembelajaran pendidikan agama Islam tidak boleh menutup mata terhadap perkembanganperkembangan tekhnologi yang disadari atau tidak memilki dampak yang sangat besar terhadap kehidupan. SD Swasta Al-Ulum medan melaksanakan Inovasi pembelajaran Pendidikan Agama Islam menggunakan dan memanfaatkan perkembangan teknologi. Misalnya, Teleconference, Google Classroom, Zoom Meeting dengan memanfaatkan fasilas seperti e-mail (surat elektronik), mobile phone, MP3 player, webse, blogging, search engine dan lain-lain. Model pembelajaran berkembang dalam bentuk pembelajaran elektronik (e-learning), buku elektronik. (e-book), kelas online, diskusi online, pembelajaran berbasis komputer. Penggunaan papan tulis dan spidol, berganti dengan penggunaan media Notebook, LCD Projector dan sebagainya. Printed material buku sumber, modul dan lembar kerja siswa berganti dengan e-book, digal library, YouTube dan laman-laman internet. Penelian ini di fokuskan pada penelian kualatif dengan menggunakan metode deskriptif. Penelian ini bermaksud meneli tentang peran alamiah Inovasi Pembelajaran Pendidikan Agama Islam di Era
\end{abstract}


Revolusi Indutri 4.0 Studi Pada SD Swasta Al-Ulum Medan. Penelian ini cocok menggunakan pendekatan penelian kualatif dengan metode deskriptif, dalam mengungkapkan fakta-fakta sebagai kebenaran empiris dalam penelian ini.

Kata Kunci: Inovasi pembelajaran, Pendidikan agama Islam, Revolusi industri 4.0, Sekolah Dasar

\section{INTRODUCTION}

The use of information technology in SD Swata Al-Ulum Medan since the assistance from the Ministry of Education at the beginning of the 2006/2007 ${ }^{1}$ academic year, where initially the information technology device and its equipment were only one unit which included a desk computer, and a printer. However, because teachers and principals use manage data and school administration. And now it is also considered to have helped teachers, even recently some teachers have privately owned laptops for learning purposes using laptops. The development of information and communication technology has in fact contributed significantly and encouraged changes in the world of education and learning. Teachers are no longer the only source in the learning process ${ }^{4}$.

This development is in the context of 4.0 in four dramatic revolutions ${ }^{5}$. The first revolution occurred when society gave education authority and trust to certain people until the "teacher profession" emerged. The second revolution occurred when writing was used as a source of learning in schools through "textbooks". The third revolution occurred when the printing press was invented, which resulted in education being more based on the diverse and widely available book sources. The fourth revolution occurs when communication technology is developing very rapidly where all materials, processes and forms of education can be transferred through technology, for that there is a need for an innovation in learning Islamic religious education in a school ${ }^{6}$.

In the past century, Muslims could only feel and guess the answer from technology. So in this century you have seen with your own eyes how sophisticated rocket technology and electronic control have succeeded in catapulting humans to the surface of the moon and returning them to earth and sending them spacecraft, each of which has a specific mission. an also tells about the most advanced means of transportation. In Surah Yasin verses 41-42 Allah says ${ }^{7}:$ And a sign for them is that We raised their offspring in an ark. full of cargo and We created for them what they would ride like an ark".

The verse describes the power of God that reminds people of their ancestors who were saved on the boat of the Prophet Noah (as). In this verse 41, Allah explains about Noah's ark

${ }^{1}$ Hasil wawancara kepsek 20 juli 2021 narasumber khairul saleh M.Pd

4 Alfurqan Alfurqan dkk., "The Problematics of Islamic Religious Education Teacher In Using of Instructional Media at SD Negeri 06 Pancung Soal Pesisir Selatan," Al-Ta Lim Journal 26, no. 1 (28 Februari 2019): 56-64, https://doi.org/10.15548/jt.v26i1.526; Umniyatul Azizah dkk., "Pemahaman Guru Terhadap Standar Isi Sekolah Lanjutan Tingkat Pertama Kota Bandung," Tafkir: Interdisciplinary Journal of Islamic Education 2, no. 2 (3 Agustus 2021): 191-206, https://pasca.jurnalikhac.ac.id/index.php/tijie/article/view/25.

${ }^{5}$ Eric Hasby, Teknologi Pendidikan (Jakarta: Bumi Aksara, 2008).

${ }^{6}$ Niswatun Hasanah, "The Role of Madrasah Ibtidaiyah in Building Student Characters in The Era Of The 4.0 Industrial Revolution," Nazhruna: Jurnal Pendidikan Islam 4, no. 2 (23 Juli 2021): 310-19, https://doi.org/10.31538/nzh.v4i2.1304; Shalahudin Ismail dkk., "The Competence of Millennial Islamic Education Teachers in Facing The Challenges of Industrial Revolution," Naz̧runa: Jurnal Pendidikan Islam 3, no. 3 (4 November 2020): 389-405, https://doi.org/10.31538/nzh.v3i3.823.

${ }^{7}$ Al-Qur`an (Jakarta: Kementerian Agama RI, 2010). 
which also gave him knowledge about how to make a boat so that it can be used. Then, in verse 42 Allah also explains information about various transformation tools that humans can use. You can see all of Allah's information and feel its existence.

The Indonesian National Education System Constitution NO. $20^{8}$ explains in Chapter I the general provisions of Article 1 point two, National education is education based on Pancasila and the 1945 Constitution of the Republic of Indonesia which is rooted in religious values, Indonesian national culture and is responsive to the demands of changing times. . Then the fifteenth point explains that distance education is education in which students are separated from educators and their learning uses various learning resources through communication technology, information, and other media. It can be translated from this point that the government has given an overview to all elements of education that demands to be careful and responsive in changing times where now we have entered the era of the industrial revolution 4.0. Furthermore, in point fifteen, the government has also allowed and approved the role of technology and other supporting media in accordance with the times.

If in the past decades, close conversations between students and teachers were taboo, today it is a natural thing. Even in the view of modern educational theory, it is a must. Such interactions are an indication of the success of the educational process. Another paradigm shift, for example in terms of learning approaches". In the era of traditional Islamic education, the teacher became a central figure in learning activities. It is the main source of knowledge in the classroom, it can even be said to be the only one. However, in the context of modern Islamic religious education, this is no longer the case. The development of information and communication technology has brought revolution in various fields of life and education. Education is a key factor in improving the quality of human resources ${ }^{10}$. The development of Islamic Religious Education learning innovations and the implementation of the current curriculum that integrates information technology in Islamic religious education learning requires teachers and students to at least be able to master technology, because this is the effect of the industrial revolution $4.0^{11}$.

Then what about the existence of education and or learning Islamic Religious Education to face this tendency. While at the same time there are many phenomena that can be observed from the learning of Islamic Religious Education today. Islamic religious education learning in schools/madrasahs seems to still have not provided innovations for learning Islamic religious education in the industrial revolution $4.0 \mathrm{era}^{12}$. Learning methods are still being developed

\footnotetext{
${ }^{8}$ Undang Undang Dasar Sistem Pendidikan Nasional Republik Indonesia NO 20

${ }_{9}$ Muljamil Qomar, Kesadaran Pendidikan: Sebuah Penentu Keberbasilan Pendidikan (Yogyakarta: Ar-Ruzz Media, 2012).

${ }^{10}$ Ahmadi, Asas dan Filsafat Pendidikan. Yogyakarta: Ar-Ruzz Media 2014

11 Bahrissalim Bahrissalim dan Fauzan Fauzan, "Evaluasi Kurikulum Pelatihan Dalam Meningkatkan Kompetensi Pedagogik Guru Pai Di Balai Diklat Keagamaan Jakarta," Edukasia: Jurnal Penelitian Pendidikan Islam 13, no. 1 (25 Juli 2018): 25-52, https://doi.org/10.21043/edukasia.v13i1.2779; Tri Hartono dan Dhenis Agus Saputro, "Pengembangan Desain Pembelajaran PAI Di Pondok Pesantren Kreatif Agro Nuur El-Falah Salatiga," Nazhruna: Jurnal Pendidikan Islam 2, no. 2 (26 Agustus 2019): 290-309, https://doi.org/10.31538/nzh.v2i2.331.

12 Ayse Demirel Ucan dan Andrew Wright, "Improving the Pedagogy of Islamic Religious Education through an Application of Critical Religious Education, Variation Theory and the Learning Study Model," British Journal of Religious Education 41, no. 2 (3 April 2019): 202-17, https://doi.org/10.1080/01416200.2018.1484695; Turah Asih Lestari dkk., "Mental Revolution of Homeless Children's Through Islamic Education Learning"
} 
with an orientation to the tradition of memorizing texts and narratives, so that Islamic Religious Education learning seems to have lost its contextualization with social realities ${ }^{13}$.

Al-ulum Medan Private Elementary School is an Islamic school owned by the Jihadul Ilmi Foundation which has been established since 1971. This year's Al-ulum Private Primary School has 995 students, the Medan city community is very enthusiastic every year they always trust their children to go to school in Medan. Al-Ulum Private Elementary School Medan. Not without reason, because Al-ulum Private Elementary School has many academic and non-academic achievements. ${ }^{14}$

As an Islamic educational institution, there are very interesting things that I have observed empirically, according to the admission of the Khairul school principal, one of the successes of the Al-Ulum Private Elementary School in Medan is responding to technological developments in the digital field, this is in line with the development of the industrial revolution era 4.0. With the support of human resources owned by this school, we are ready to compete with other schools. In terms of learning, this school has also been supported by uses such as using infocus, using laptops, and filling out student assessments through assistance, then in public service information services the answer is. Such as utilizing web information technology from the service side, especially as a means for Al-Ulum Private Elementary School to provide information services quickly, clearly and accountably.

This school has conducted digital-based Islamic Religious Education learning. I see that some of the supporting facilities for learning Islamic Religious Education have begun to carry out digital-based learning based on Information Technology. This article aims to describe IRE (Islamic Religious Education) learning innovations at Al-Ulum Elementary School Medan.

\section{METHOD}

This research was conducted at SD Swata Al Ulum Medan Accreditation Area A Address Jl. Castle No. 154/346 Medan 20215 Postal code 20215 Phone Number 061-7369408 Email sds.al_ulum@ymail.com Urban Village Matsum Postal Code 20215 Medan District Area Medan City North Sumatra Province This research time is from October 2020 to August 2021. The background in this research is "Innovation of Islamic Religious Education Learning in the Industrial Revolution 4.0 Era Studies at Al-Ulum Private Elementary School Medan". The location of the research that I will do is at SD Swata Al Ulum Medan Accreditation Area A Address Jl. Castle No. 154 / 346 Medan. Matsum City Village, Postal Code 20215, Medan District, Medan City Area, North Sumatra Province.

Research methodology is a procedure or procedure for carrying out all research activities. The type of research used in this research is qualitative research using a descriptive

(International Conference on Engineering, Technology and Social Science (ICONETOS 2020), Atlantis Press, 2021), 67-72, https://doi.org/10.2991/assehr.k.210421.011.

13 Mukhammad Abdullah, "School Culture to Serve Performance of Madrasah in Indonesia," QIJIS (Qudus International Journal of Islamic Studies) 7, no. 1 (3 Juni 2019): 71, https://doi.org/10.21043/qiijs.v7i1.4809; Nana Herdiana Abdurrahman, "Character Education in Islamic Boarding School- Based Sma Amanah," Jurnal Pendidikan Islam 2, no. 2 (21 Juni 2016): 287-305, https://doi.org/10.15575/jpi.v2i2.791.

${ }^{14}$ Wawancara kepsek SD swasta Alulum juli 2021 
approach. According to Taylor ${ }^{15}$ qualitative research is a research procedure that produces descriptive data in the form of written or spoken words from people and observed behavior. Qualitative research implies an effort to explore and understand the meaning of what is happening to various individuals and groups originating from social or humanitarian issues ${ }^{16}$.

The data source is the subject where the data can be obtained. Basically, there are two sources of data in this research. The first is library data, articles, journals, books, documentation and so on. The second data source is empirical field data. This data was collected through observations and interviews with both foundation managers, teachers, parents and students. The main data sources are in the form of words and actions of the subject that are the focus of research, the rest is in the form of additional data such as documents, photos and others. The main data sources are recorded through interviews or taking photos. Meanwhile, additional data were obtained from written sources, such as theses, journals, articles, and data related to learning in the fifth grade of Al-Ulum Private Elementary School Medan. The informants in this study included foundation managers, teachers, guardians of students and children who took part in learning activities in class V of Al-Ulum Private Elementary School Medan.

\section{RESULTS AND DISCUSSION}

\section{Implementation of Islamic Religious Education Learning Innovations at Al-Ulum Private Elementary School Medan}

In relation to the curriculum used at $\mathrm{Al}$ Ulum private elementary school, $\mathrm{Al}$ Ulum Medan, two curricula are used at once, namely: 2006 KTSP curriculum and 2013 curriculum. The 2006 KTSP curriculum has the characteristics or characteristics of schools that give it great authority to compile it, of course, taking into account the objective conditions of each school. The 2006 KTSP curriculum is famous for its three approaches, namely: exploration, explanation and confirmation ${ }^{17}$. The 2006 KTSP curriculum has only been used in this school for a long time. So far, this education unit still maintains the 2006 KTSP as a learning reference. Therefore, the involvement of private elementary school teachers at AL Ulum Medan in seminars, workshops, and trainings on the curriculum can be said to be rarely followed.

While the 2013 curriculum is more directed to a scientific approach by using five approaches, namely: observing, questioning, associating, experimenting and communicating. Al Ulum Medan private elementary school has been using the 2013 curriculum since the beginning until now. The use of the scientific curriculum (K-13) entirely adopts or uses the curriculum issued by the Ministry of National Education as a whole. The 2013 curriculum is a

${ }^{15}$ Robert Bogdan dan Sari Knopp Biklen, Qualitative research for education: an introduction to theory and methods, 3rd ed (Boston: Allyn and Bacon, 1998).

${ }^{16}$ Engkus Kuswarno, "Tradisi Fenomenologi pada Penelitian Komunikasi Kualitatif: Sebuah Pengalaman Akademis," MediaTor (Jurnal Komunikasi) 7, no. 1 (2006): 47-58.

17 Al-Tabany, T.I.B. (2014). Mendesain Model Pembelajaran Inovatif Progresif dan Kontekstual. Jakarta: Kencana Prenada Media Group. 
national curriculum that is applied throughout Indonesia. Therefore, the private SD Al Ulum Medan refers to and uses this curriculum as a whole. ${ }^{18}$

In addition, this school also uses the Ministry of Religion curriculum as a "balancing" curriculum to prepare students to become intelligent, faithful and pious Muslims. This is in line with the statement made by the chairman of the Education Foundation (Yayasan) through an interview on June 3, 2021 as follows:

"The curriculum used at the Al Ulum private elementary school in Medan comes from the Ministry of National Education (2013 curriculum) and the curriculum from the Ministry of Religion. Therefore, for the curriculum from the Ministry of Religion, this school makes adjustments that pay attention to students as study subjects."

Based on the interview, it can be understood that the curriculum that comes from the Ministry of Religion and the 2013 curriculum is the main reference that students must learn in the learning process according to the level they are following. Therefore, so that the two curricula can be implemented properly and students as learning subjects can understand them with the specified skills, the principal conducts socialization to all teachers while carrying out the function of academic supervision. The aim is to transfer all the material contained in the curriculum, both from the Ministry of Religion and the curriculum from the Ministry of National Education.

The use of the 2013 curriculum is used because it has characteristics that are in accordance with the educational goals to be achieved by Al Ulum private elementary school, stating that the 2013 curriculum has the following characteristics: 1) Develop a balance between spiritual and social attitudes, knowledge, and skills, and apply them in various situations in school and society. 2) Placing the school as part of the community that provides learning experiences so that students are able to apply what is learned in school to the community and utilize the community as a learning resource. 3) Give enough time to develop various attitudes, knowledge, and skills. 4) Develop competencies that are stated in the form of class core competencies which are further detailed in the basic competencies of subjects. 5) Develop class core competencies into organizing elements (organizing elements) of basic competencies. All basic competencies and learning processes are developed to achieve the competencies stated in the core competencies. 6) Develop basic competencies based on the principle of accumulative, mutually, reinforcing, and enriched between subjects and levels of education (horizontal and vertical organization). ${ }^{19}$

The interview with the Deputy Principal for curriculum on June 4, 2021 was stated as follows:

"Al Ulum Medan private elementary school until now uses two curricula simultaneously in the learning process. The first curriculum is the 2006 KTSP and the second is the 2013 curriculum with

18 Imas Kurniasih dan Berlin Sani, Implementasi kurikulum 2013: konsep \& penerapan (Yogjakarta: Kata Pena, 2014); E. Mulyasa, Pengembangan dan implementasi kurikulum 2013, Cetakan pertama (Bandung: PT Remaja Rosdakarya, 2013).

19 Sanjaya Wina, Kurikulum dan Pembelajaran: Teori dan Praktik Pengembangan Kurikulum Tingkat Satuan Pendidikan (KTSP), 6 ed. (Jakarta: Kencana Prenada Media Group, 2015); Muhammad Anas Maarif dan Muhammad Husnur Rofiq, "Pola Pengembangan Kurikulum Pendidikan Pesantren Berkarakter: Studi Implementasi Pendidikan Berkarakter di Pondok Pesantren Nurul Ummah Mojokerto” 13 (2018): 16. 
a scientific approach. However, in practice, there are still many obstacles, this is related to the knowledge and ability of teachers to implement the curriculum in the learning process in the classroom. However, according to the agreement, this school uses two curricula simultaneously."

Based on the interview, it can be interpreted that the school's efforts to improve learning outcomes of Islamic Religious Education in Al Ulum Private Elementary School Medan have received high attention from schools and foundations. This statement is supported by several facts which show that the implementation of the two KTSP curricula and the science-based curriculum is still running, although in practice there are many obstacles. For example, the obstacle comes from the teacher, because not all teachers have attended training or seminars on the curriculum. In addition, the limitations of learning facilities and infrastructure also contribute to the not yet maximal implementation of the curriculum.

The implementation of the curriculum at the Al Ulum private elementary school in Medan is divided into two, namely: (1) the curriculum from the Ministry of National Education, and (2) the curriculum issued by the Ministry of Religion. The curriculum that comes from the Ministry of National Education is the curriculum set by the government as the controller of education at the central level. The curriculum is written in accordance with the vision, mission, and goals of national education as stipulated in the law. Meanwhile, the curriculum issued by the Ministry of Religion has a content of religious lessons plus general lessons. Regarding the comparison of the number of religious and general lessons at an Islamic educational institution, it depends on the institution concerned ${ }^{20}$.

As an effort to achieve the goals as stated in the vision and mission of the private SD Al Ulum Medan, in the application of the learning process, a student-dominated class is applied. This means that students are given more opportunities to seek, find and decide on various information (subject matter) conveyed by the teacher in the classroom through exercises, guidance, and so on and not vice versa in teacher-dominated learning.

Based on the facts that the authors found in the field, actually the managers of the $\mathrm{Al}$ Ulum Medan private elementary school, in particular, all the teachers who teach at the institution are familiar with the current curriculum, for example KBK, KTSP and 2013 Curriculum. in the learning and teaching process. For this reason, the following will describe matters relating to the learning process of Islamic Religious Education.

Another finding can be expressed in terms of innovation from the aspect of using IT in the learning process. For example the use of Google Classroom. Google classroom is learning by utilizing internet technology to enhance a learning environment with rich content with a wide scope. The learning is the use of learning media using the internet, to deliver a series of solutions that can improve knowledge and skills. Each learning method must contain the formulation of the organization of learning materials, delivery strategies, and management of

20 Mhd Reza Fahlevi, Asnil Aidah Ritonga, dan Wahyuddin Nur Nasution, "The Relevance of The Madrasah Aliyah Fiqh Package Book Published By The Indonesian Ministry of Religion With The 2013 Curriculum," Ną̧hruna: Jurnal Pendidikan Islam 4, no. 2 (19 Agustus 2021): 460-76, https://doi.org/10.31538/nzh.v4i2.1605; Miftachul Huda dan Mulyadhi Kartanegara, "Curriculum conception in the perspective of the book ta'lim al-muta'allim," International Journal of Education and Research 3, no. 2 (2015): 22132. 
activities by taking into account the factors of learning objectives, learning barriers, characteristics of students, in order to obtain effectiveness, efficiency, and attractiveness of learning ${ }^{21}$.

This application is a new breakthrough created by Google which with its sophistication allows the creation of classrooms without a face-to-face process. Students who are members of the application can check every assignment given by the teacher on the task page available in the application in an easy way with just one click. So, they immediately respond to tasks sent through the application. To make it easier to operate, you can learn by paying attention to the steps that we will explain below: Open the google page via the Mozilla Firefox or Google Chrome page, then open the Google classroom link. Some of the requirements to be able to use this Google Classroom are as follows:

Teachers and students already have Google Apps for Education accounts: Teachers and students who will join the class must have that account, by having that account teachers and students can apply google classroom. Next, visit the classroom.google.com site and sign in. The teacher as the class organizer can click on the teacher's writing to create a class. On the other hand, if you are a student, click on the student's writing so you can join the class created by the teacher using the code that has been obtained.

Teachers add students directly or share code: This step is done in class by telling students to join the class created by the teacher. He informed students that he would apply google classroom to the subjects he taught. The teacher instructs the students to activate the teacher's email as a tutor in the classroom.

The teacher gives independent assignments: This task is given by the supporting teacher as a tutor to throw it independently to be done at home or during group study. Assignments sent by the teacher through Google Classroom will automatically be saved to the Google Drive folder.

The teacher throws information about the discussion: In addition to giving individual or group assignments. This application can provide information according to the theme of PAI lessons that are delivered to students in accordance with the Learning Implementation Plan (RPP).

This google application can be accessed on a PC and can be accessed via a mobile phone or tablet based on android/iOS. Lecturers and students can visit the site https://classroom.google.com on google or can download it via the playstore on android. Its use is free of charge, so it can be used as needed. Learning by using this google classroom application can connect teachers and students ${ }^{22}$.

This application will make it easy for educators (teachers) to explore their scientific ideas which are then given to students. Teachers have the flexibility of time or more opportunities to share knowledge and provide tasks that are done outside of school or commonly called independent assignments (take home) to their students. In addition, teachers also give the students the opportunity to become familiar with technology.

${ }^{21}$ Ibrahim Bafadal, Peningkatan profesionalisme guru sekolah dasar dalam kerangka manajemen peningkatan mutu berbasis sekolah, Cet. 1, Seri manajemen peningkatan mutu pendidikan berbasis sekolah (Jakarta: Bumi Aksara, 2003).

22 Nanang Hasan Susanto, “The Walisongo's Educational Leadership through Modelling and Fulfilment of Human Basic Needs," Jurnal Pendidikan Islam 6, no. 2 (27 Desember 2017): 311-30, https://doi.org/10.14421/jpi.2017.62.311-330. 
The use of computers as learning media in Google Classroom generally follows the following instructional process: 1) Plan, organize, organize and schedule teaching. In this application, various lessons have been designed to achieve a PAI learning goal. Google Classroom is also concerned with grouping and scheduling the teaching of religious subjects. 2) Evaluating students. Google Classroom can be used as a student evaluation material. For example, students take exams through the Google Classroom application, before taking the exam, the teacher first uploads questions in this application. 3) Collecting student data information. In Google Classroom there is student data, which facilitates the assessment and teaching process. The information includes complete student biodata, student grades, student activity data on the google classroom application. 4) Conduct statistical analysis of learning data. Statistical analysis in google classroom aims to collect student data. The data collected such as, student creativity and student activity in the application. 5) Notes on the development of group and individual learning processes. Notes on the progress of group or individual learning in Google Classroom are very important. as a student evaluation material to see how far students are active in the Google Classroom application.

Through Google Classroom, it is hoped that IRE learning in schools will be more optimal and effective in accordance with the demands of a modern era and learning in schools is expected to produce something planned at the beginning of the school year according to the existing curriculum, which is of course the vision and mission that has been planned by the school and always be their motto every day can be achieved as expected. Learning strategies must be able to encourage student activity.

\section{Zoom Application Implementation}

This application was developed by Zoom Video Communications, an American communications technology company headquartered in San Jose, California. The company, which was founded by Eric Yuan in 2011, provides video conferencing and online chat services that are commonly used for teleconferencing, remote work, distance learning, and social contact. This service is provided free of charge for video conferencing meetings for up to 100 users with a time limit of up to 45 minutes in one video conference sign-in. To extend the time and increase the number of users, the Zoom application also provides subscription services at a cost ranging from $\$ 16-\$ 20$ per month.

Based on the explanation above, the author can understand that the Zoom cloud meetings application is an application that provides video service features that can connect 2 to 100 users in a video conference room, apart from that, Zoom also provides chat services and is equipped with a share scran feature. which can serve to display something that we want to share and we will explain it to all members who are members of the video conference.

Using media in the form of applications in the application of learning certainly brings its own positive impact both for educators and for students. However, before using the application, educators and students must first know what features can be provided and how to operate the application. Here are the steps on how to use the Zoom cloud meetings application:

Download the application, the zoom cloud meetings application can be downloaded using a cellphone via the play store or apple store and if using a computer the zoom cloud 
meeting application can be downloaded at https://zoom.us/download. After downloading the application, the next step is to open the installed application. After opening the application, the following screen will appear. Then the next step students enter the meeting ID and password that has been provided by the educator, after that click join. Apart from the 2 steps above, it can also be done with other alternatives, namely by clicking on the meeting link that has been shared by the educator. And then the educators and students are connected in a video meeting.

\section{Implementation of Learning with the Whatsapp Application}

WhatsApp is an application designed to facilitate communication in the midst of current technological developments. WhatsApp is part of social media that makes it easy and allows all users to share information. The use of WhatsApp has been used by various groups of people because of its easy use. In line with Jumiatmoko's opinion, that WhatsApp is an internet-based application that makes it easy for users to communicate with the available features and is the most popular social media used in communicating. 83\% of 171 million internet users are WhatsApp users ${ }^{23}$.

Suryadi states that WhatsApp is a means of communicating by exchanging information both text messages, images, videos and even telephones. This opinion can be seen that WhatsApp provides convenience in conveying information. Afnibar's opinion states that the use of WhatsApp will make it easier for users to convey information more quickly and effectively. So WhatsApp can provide effectiveness in communicating, interacting easily and quickly, especially in conveying learning information.

Thus the researcher concludes that WhatsApp is an internet-assisted instant application, which is able to facilitate its use with the features presented. The use of WhatsApp has also become a communication tool that is widely used among the community because of its easy users, especially its use in learning. The preparations made by the teacher are as follows.

The teacher creates a class whatsapp group that will be used: The first step is to create a study group. This group will be used as an online class, both for material giving activities, exercises, assignments, etc. After creating a group, the teacher invites students to join the online class that has been created. you can enter one by one, or you can invite students via a link. The teacher determines the schedule and plan used: For regular and structured learning activities, please make a study schedule and study plan. Just make a schedule and inform the group when the day and time of learning activities are.

Tabel 1. Activity schedule table

\begin{tabular}{llll}
\hline No & Jenis kegiatan & Waktu & $\begin{array}{l}\text { Jenis } \\
\text { penilaian }\end{array}$ \\
\hline $\mathbf{1}$ & Siswa mengisi absen online & $08.00-08.15$ & \\
$\mathbf{2}$ & Pemberian materi belajar & $08.15-08.30$ & \\
$\mathbf{3}$ & Diskusi materi & $08.30-09.00$ & \\
$\mathbf{4}$ & Pemberian tugas & $09.00-10.00$ & Tes online \\
\hline
\end{tabular}

${ }^{23}$ Muhtar Tajuddin dan Imam Syafi'i, "Blended Learning Model of Ulumul Hadith Through Whatsapp Media," Nazhruna: Jurnal Pendidikan Islam 4, no. 2 (12 Juni 2021): 162-79, https://doi.org/10.31538/nzh.v4i2.1194. 
Preliminary activities: In the preliminary learning activities, the teacher greets students through the WhatsApp group by greeting, then proceeds to send online attendance using the google form and send a link to the class WhatsApp group. Then the teacher gives instructions for the activities to be carried out. After the teacher sends attendance, students fill in the attendance list, and those who have been absent will automatically record the names of those who have filled in the absences.

Core Activities: In core activities the teacher provides opportunities for students, and states that they understand the tasks that have been given, the teacher continues learning activities by giving assignments, the tasks given are in the form of LKPD that has been made by the teacher. The teacher gives the time for sending assignments until $21.00 \mathrm{WIB}$, this is because there are some students who use their parents' cellphones, and wait for their parents to come home from work first, after that they can only do the assigned tasks. The assignments given can be collected in the form of photos and sent to the WhatsApp group or sent directly to the teacher. For students who are late in submitting assignments until the specified time limit, they can still submit the next day, but must include a logical reason.

Closing activity: The learning activity is ended by the teacher closing the lesson by giving appreciation with thanks, funny stickers, and the WhatsApp icon in the form of a thumbs up to students who have followed the lesson well.

\section{Learning Evaluation}

After the researchers made observations, the evaluation system carried out by the teacher was that after all the tasks given to students had been accepted by the teacher, the teacher would correct one by one the tasks that were entered in the WhatsApp group or personal chat and enter the students' scores into the score notebook as physical evidence of student assessment. Then the accumulated value will be obtained from the results of the test and also the tasks that have been done, for students who have not done or scored below the $\mathrm{KKM}$, the teacher will provide information via personal chat directly to the person concerned.

Attendance that has been filled in via the google form, the teacher will recapitulate all student attendance, into the teacher's absence book, as physical evidence. Furthermore, through activities using WhatsApp, the teacher reports the results of learning activities into student learning activity reports that are made every day, and reported to the principal every week.

The assessment is carried out in the form of an assessment of attitudes, knowledge and skills. In the current condition of distance learning activities to assess the attitudes of students by looking at their politeness and discipline when interacting in WhatsApp Groups, the assessment of knowledge is seen from how well they understand the existing material by doing assignments, such as giving LKPD, as well as assessing skills by looking at the results of the work in the form of writing, the crafts they do.

Terkait dengan proses pembelajaran Pendidikan Agama Islam, SD swasta Al Ulum Medan telah menggunakan beberapa media baik yang dirancang oleh guru PAI sendiri maupun media yang termasuk kategori mahal, seperti laptop dan in focus. Hal ini dilaksanakan ketika pembelajaran masih tatap muka sebelum terjadi pandemi covid-19 terjadi. Namun situasi tersebut berobah, di mana pembelajaran harus dilakukan secara daring. 
Related to the learning process of Islamic Religious Education, Al Ulum private elementary school Medan has used several media, both designed by the IRE teachers themselves and media that are included in the expensive category, such as laptops and in focus. This was carried out when learning was still face-to-face before the COVID-19 pandemic occurred. But the situation has changed, where learning has to be done online. An interview with a class teacher on June 9, 2021 is as follows:

"The process of teaching Islamic Religious Education in the classroom uses laptop media which is connected to in focus. Even the wi fi internet network can also be accessed in the classroom. In focus is in each study room, so teachers only bring their own computers in the form of laptops. I have been using this laptop since teaching at this school".

The author also conducted a study of documents related to learning media innovation. Based on existing documents, it was found that IRE teachers at SD Al Ulum Medan had used sophisticated (sophisticated) learning media, such as: laptops, infocus and also used the audiovisual room. In learning activities, the teacher selects and uses appropriate learning resources and learning media in accordance with the objectives and learning materials. Therefore, as a teacher, it is very important to know the various types of learning resources and learning media and their characteristics, the types and benefits of learning resources and learning media, as well as the main characteristics of certain types of media, as well as the criteria for selecting and using them.

Learning media is used with the aim of improving the quality of the teaching and learning process which in turn is expected to improve student learning outcomes. There are several reasons for the importance of using learning media in an effort to improve the quality of the process and student learning outcomes. The main reason is related to the ability of the media to make abstract subject matter more concrete and clearer. As it is known that something learned will be easier to understand and remember if it is obtained through concrete experience that involves many senses.

Other reasons are related to the benefits that can be obtained through the use of the media itself, which include: 1) It can make the learning process more interesting and more interactive because the use of media can increase students' curiosity, positive attitude and motivation to learn. This will affect students' love of science and the process of seeking knowledge. 2) Can overcome the limitations of space, time, and sensory power because it can be used to manipulate objects and events, including: a) Dangerous objects, which are too large, too small or too complex can be studied through drawings or models by reducing the size. small, oversimplify complex, or set too fast and too slow motion. b) Events and procedures that need to be observed repeatedly in studying them can be recorded, photographed and displayed again through video and audio recordings, films, chain films, or frame films. 3) Can clarify, uniform and streamline the presentation of learning materials, with the media being prepared in advance, many things can be considered and done to make the presentation of learning materials clearer, more systematic, and more efficient.

Based on the results of these interviews, it can be understood that the learning process of Islamic Religious Education in Al Ulum Private Elementary School Medan is carried out by teachers using media as a tool to deliver subject matter. The media used in the learning 
process has been designed in such a way in the form of power points/slides. Furthermore, the slides that have been designed in such a way as to contain the subject matter are projected through in focus which can be seen by students together in front of the class.

Presentation of material in this way will bring two benefits, namely: benefits for teachers and students. For teachers, the benefit is to reduce large activities so that the energy expended by the teacher is not too large. As for students, the benefits are to help and make it easier to understand the material presented by the teacher. The results of students' understanding based on interviews and observations were very good. Most students can accept and understand the material conveyed by the teacher.

In the practice of learning in the classroom, Islamic Religious Education teachers at the private elementary school Al Ulum Medan provide a fairly large function and role of the media. In this learning context, the functions and roles are taken over by the media but not as a whole. There are still functions and roles of teachers to manage the learning process. Control of learning activities is shared between the teacher and the media.

There are four learning patterns that are generally carried out by teachers, namely as follows. Pattern (1), student learning resources are only in the form of people. The teacher or lecturer has full control over the occurrence of learning activities. Pattern (2), learning resources in the form of people assisted by other sources. However, in this pattern the teacher is still in control but not absolutely because he is assisted by other sources. In this pattern, sources that function as tools are called teaching aids. Pattern (3), the source together with other sources based on the division of responsibilities. In this case, control over teaching and learning activities is shared between human resources and other sources. And these other sources are an integral part of all teaching and learning activities. In this pattern other sources are called media. Pattern (4), students only learn by using one non-human resource. This situation occurs in a teaching through the media. And non-human sources are called media.

In connection with the IRE learning media innovation at the Al Ulum private elementary school, Medan, the four patterns mentioned above are used. However, the frequency that is more often used is pattern 3 , in which the learning control is divided equally between teachers and students.

\section{CONCLUSION}

Al Ulum private elementary school Medan has implemented the 2013 curriculum with a science-based approach and a curriculum from the ministry of religion. These two curriculum models are simultaneously used in the whole learning process. To activate students in learning, teachers can use a process and learning skills approach as a reference for the development of intellectual, social and physical skills that come from the basic abilities that already exist in students. By using the process skills approach and active learning, students will (a) gain a proper understanding of the nature of knowledge, (b) have the opportunity to learn with science, (c) have the opportunity to process and obtain learning outcomes through direct experience.

Media used. In general, the media and learning resources at the Al Ulum private elementary school in Medan are quite good. To produce learning effectiveness and improve student learning outcomes optimally, the use of media and learning resources is absolutely 
done by the teacher. Al Ulum private elementary school in the 2007 academic year has carried out information technology-based learning characterized by the industrial revolution 4.0. Teachers continue to upgrade the current developments so that they innovate Islamic religious education learning by using applications in the industrial revolution era such as google classroom, zoom, whaatsap. Students are very happy to learn with the sophistication of information technology as it is today in the era of the industrial revolution, it's just that the economic limitations of most students so they have to struggle to follow the lessons. The principal has responded positively to the development of IRE learning in the 4.0 era because we also have to adjust learning according to the demands of the times, he said.

\section{REFERENCES}

Abdullah, Mukhammad. "School Culture to Serve Performance of Madrasah in Indonesia." QIJIS (Qudus International Journal of Islamic Studies) 7, no. 1 (3 Juni 2019): 71. https://doi.org/10.21043/qiiis.v7i1.4809.

Abdurrahman, Nana Herdiana. "Character Education in Islamic Boarding School- Based Sma Amanah.” Jurnal Pendidikan Islam 2, no. 2 (21 Juni 2016): 287-305. https://doi.org/10.15575/jpi.v2i2.791.

Alfurqan, Alfurqan, M. Tamrin, Zulvia Trinova, dan Zuhdiyah Zuhdiyah. "The Problematics of Islamic Religious Education Teacher In Using of Instructional Media at SD Negeri 06 Pancung Soal Pesisir Selatan." Al-Ta Lim Journal 26, no. 1 (28 Februari 2019): 5664. https://doi.org/10.15548/jt.v26i1.526.

Al-Qur`an. Jakarta: Kementerian Agama RI, 2010.

Azizah, Umniyatul, Chairul Rahman, Ida Farida, dan Nina Nurmilasari. "Pemahaman Guru Terhadap Standar Isi Sekolah Lanjutan Tingkat Pertama Kota Bandung." Tafkir: Interdisciplinary Journal of Islamic Education 2, no. 2 (3 Agustus 2021): 191-206. https://pasca.jurnalikhac.ac.id/index.php/tijie/article/view/25.

Bafadal, Ibrahim. Peningkatan profesionalisme guru sekolah dasar dalam kerangka manajemen peningkatan mutu berbasis sekolah. Cet. 1. Seri manajemen peningkatan mutu pendidikan berbasis sekolah. Jakarta: Bumi Aksara, 2003.

Bahrissalim, Bahrissalim, dan Fauzan Fauzan. "Evaluasi Kurikulum Pelatihan Dalam Meningkatkan Kompetensi Pedagogik Guru Pai Di Balai Diklat Keagamaan Jakarta." Edukasia : Jurnal Penelitian Pendidikan Islam 13, no. 1 (25 Juli 2018): 25-52. https://doi.org/10.21043/edukasia.v13i1.2779.

Bogdan, Robert, dan Sari Knopp Biklen. Qualitative research for education: an introduction to theory and methods. 3rd ed. Boston: Allyn and Bacon, 1998.

Demirel Ucan, Ayse, dan Andrew Wright. "Improving the Pedagogy of Islamic Religious Education through an Application of Critical Religious Education, Variation Theory and the Learning Study Model." British Journal of Religious Education 41, no. 2 (3 April 2019): 202-17. https://doi.org/10.1080/01416200.2018.1484695.

Fahlevi, Mhd Reza, Asnil Aidah Ritonga, dan Wahyuddin Nur Nasution. "The Relevance of The Madrasah Aliyah Fiqh Package Book Published By The Indonesian Ministry of Religion With The 2013 Curriculum." Nazhruna: Jurnal Pendidikan Islam 4, no. 2 (19 Agustus 2021): 460-76. https://doi.org/10.31538/nzh.v4i2.1605. 
Hartono, Tri, dan Dhenis Agus Saputro. "Pengembangan Desain Pembelajaran PAI Di Pondok Pesantren Kreatif Agro Nuur El-Falah Salatiga.” Nazḩruna: Jurnal Pendidikan Islam 2, no. 2 (26 Agustus 2019): 290-309. https://doi.org/10.31538/nzh.v2i2.331.

Hasanah, Niswatun. "The Role of Madrasah Ibtidaiyah in Building Student Characters in The Era Of The 4.0 Industrial Revolution.” Ną̧hruna: Jurnal Pendidikan Islam 4, no. 2 (23 Juli 2021): 310-19. https://doi.org/10.31538/nzh.v4i2.1304.

Hasby, Eric. Teknologi Pendidikan. Jakarta: Bumi Aksara, 2008.

Huda, Miftachul, dan Mulyadhi Kartanegara. "Curriculum conception in the perspective of the book ta'lim al-muta'allim." International Journal of Education and Research 3, no. 2 (2015): 221-32.

Ismail, Shalahudin, Ma'mun Zahrudin, Uus Ruswandi, dan Erihadiana Erihadiana. "The Competence of Millennial Islamic Education Teachers in Facing The Challenges of Industrial Revolution." Nazhruna: Jurnal Pendidikan Islam 3, no. 3 (4 November 2020): 389-405. https://doi.org/10.31538/nzh.v3i3.823.

Kurniasih, Imas, dan Berlin Sani. Implementasi kurikulum 2013: konsep \& penerapan. Yogjakarta: Kata Pena, 2014.

Kuswarno, Engkus. "Tradisi Fenomenologi pada Penelitian Komunikasi Kualitatif: Sebuah Pengalaman Akademis." MediaTor (Jurnal Komunikasi) 7, no. 1 (2006): 47-58.

Lestari, Turah Asih, Muhammad Anas Ma'arif, Ari Kartiko, Ahmad Karim, dan Barham Siregar. "Mental Revolution of Homeless Children's Through Islamic Education Learning," 67-72. Atlantis Press, 2021. https://doi.org/10.2991/assehr.k.210421.011.

Maarif, Muhammad Anas, dan Muhammad Husnur Rofiq. "Pola Pengembangan Kurikulum Pendidikan Pesantren Berkarakter: Studi Implementasi Pendidikan Berkarakter di Pondok Pesantren Nurul Ummah Mojokerto" 13 (2018): 16.

Mulyasa, E. Pengembangan dan implementasi kurikulum 2013. Cetakan pertama. Bandung: PT Remaja Rosdakarya, 2013.

Qomar, Muljamil. Kesadaran Pendidikan: Sebuah Penentu Keberbasilan Pendidikan. Yogyakarta: ArRuzz Media, 2012.

Susanto, Nanang Hasan. “The Walisongo's Educational Leadership through Modelling and Fulfilment of Human Basic Needs." Jumal Pendidikan Islam 6, no. 2 (27 Desember 2017): 311-30. https://doi.org/10.14421/jpi.2017.62.311-330.

Tajuddin, Muhtar, dan Imam Syafi'i. "Blended Learning Model of Ulumul Hadith Through Whatsapp Media.” Ną̧hruna: Jurnal Pendidikan Islam 4, no. 2 (12 Juni 2021): 162-79. https://doi.org/10.31538/nzh.v4i2.1194.

Wina, Sanjaya. Kurikulum dan Pembelajaran: Teori dan Praktik Pengembangan Kurikulum Tingkat Satuan Pendidikan (KTSP). 6 ed. Jakarta: Kencana Prenada Media Group, 2015. 